\title{
Party strategies and performances in the 2019 Provincial Elections in Ecuador
}

\author{
Régis Dandoy
}

Recepción: 1 de septiembre de 2019

Aprobación: 25 de octubre de 2019

\begin{abstract}
This article investigates provincial elections in Ecuador and observes the degree to which they can be explained by national factors or whether these elections displayed their own (provincial) dynamics. Using a novel typology of parties based on their territorial dimension and the presence of provincial parties, it combines an analysis of the supply-side (electoral lists) and of the demand-side (voting behaviour) of these elections. The performance of the main political parties and alliances for the 2014 and 2019 provincial elections is investigated and regression analyses demonstrate that the type of party has a direct impact on its electoral performance. It concludes that provincial parties are important actors in the provincial elections in Ecuador. Provincial parties are the most successful stand-alone type of parties, and when they join an electoral alliance with other political parties, their beneficial effect on election results is reinforced.
\end{abstract}

Keywords

Ecuador, Provincial elections, Prefects, National parties, Provincial parties 


\section{Introduction}

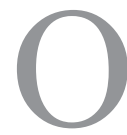

$\mathrm{n}$ the 24 March 2019, more than 13 million of Ecuadorians were called to elect their new representatives for a series of national and subnational institutions. Voters had to fill in between six and eight different ballots depending on their municipalities. Ecuador is administratively and politically decentralised in three main different levels of government: 24 provinces, 221 cantons and 1499 parishes. Each level benefits from a relative autonomy compared to the national level and has its own directly elected representatives. Subnational elections in Ecuador consist in a mix of executive and legislative elections: executive elections at the provincial level, both executive and legislative elections at the municipal level and legislative elections at the parochial level.

This article focuses on the analysis of the 2019 provincial elections and compares them with the previous elections of 2014. Given that the subnational legislative elections in Ecuador are rather complex (two different types of local councillors and an electoral system based on panachage), it is methodologically more convenient to analyse the elections of the provincial prefects. At the provincial level, there are no legislative elections and the candidate that attracts the largest amount of votes is designated as prefect. There is no second round and no minimal thresholds of turnout or valid vote shares for the winning candidate. Given the relative low number of provinces (there are 23 provincial elections as the province of Galapagos does not elects its head of provincial executive), it is also easier to observe voting behaviour at this level of government. In addition, since provinces constitute the intermediary level between the canton and the national state, it is the most suitable level for observing the territorial dynamics of national and subnational parties ${ }^{2}$.

\footnotetext{
1.- In this article, I use the English translation of the official terms rather than the more commonly accepted terms in the political science literature. More precisely, the 'provincial' elections in Ecuador correspond to regional elections while the 'prefectural' elections correspond to the gubernatorial elections. I refer indistinctively to the 'cantonal' or 'municipal' level of government when discussing political phenomena at the canton level, for instance the mayoral or the urban and rural council elections.

2.- Not to mention the fact that the large majority of the subnational parties that compete in the mayoral elections are not cantonal parties but provincial parties (Dandoy, 2014).
} 
Several elements characterize the context of the 2019 provincial elections. The weakening of the dominant party Alianza PAIS since the presidential elections of 2017 provoked two phenomena. First, it increased significantly party competition, as smaller candidates and parties believed that they could have a unique opportunity to win some, as Alianza PAIS was leaving a political vacuum that could be easily filled. Second, and contrary to the 2014 provincial elections, that were considered as a national referenda pro- or contra- Correa and his policy project (Pachano 2015; Welp et al. 2018), the influence of national parties should be proportionally diminished and make way to provincial actors. Yet, the position of the 2019 provincial elections in the Ecuadorian electoral calendar exactly in the midpoint inbetween two national elections (this phenomenon is also known as the 'midterm elections' - see for instance Miller and Mackie 1973; Tufte 1975) should theoretically benefit to the main national opposition parties.

Another important feature of the electoral calendar is the fact that provincial elections are organised simultaneously with other types of elections. In provinces hosting a large city such as Quito or Guayaquil, prefectural elections compete with mayoral elections for the occupation of the political and media agendas, while prefectural elections are proportionally more important in provinces that witness a no major city. However, in these elections, the attention of the political actors, the media, and the civil society was also on the first direct elections of an institution located at the national level: the Council for Citizen's participation and social control (CPCCS). The debate around the usefulness of this institution overshadowed the prefectural elections in the last few weeks of the campaign. Several prominent political actors called for a strategic use of null and blank votes and this call could have had in return an impact on voting behaviour in other elections organized in the same day. Given that voting is compulsory in Ecuador, turnout for the provincial elections reached $82,78 \%$, which represents a slight increase compared to 2014 where voters reached $82,47 \%$. Given the potential impact of the widespread call for expressing null and blank votes for the CPCCS elections during the campaign, the share of blank votes increased to $10,41 \%$ (compared to $7,95 \%$ in 2014) while the share of null votes was even higher with $13,59 \%$ (compared to 8,52 $\%$ in 2014) of the total number of registered votes. 
Territory is a relevant dimension for the analysis of electoral processes in Ecuador. Election results vary across provinces and many authors stressed the existence of differences between the characteristics of the party system at the national level and at the provincial level for the national elections (see for instance Sánchez 2008; Polga-Hecimovich 2014; Pachano 2015; Freidenberg and Pachano 2016). This article attempts to contribute to the growing debate in the literature on elections in Ecuador regarding the provincialization vs. nationalization of the national elections (Polga-Hecimovich 2014; Došek 2015; Freidenberg and Pachano 2016; Dandoy 2017). Moreover, the inclusion of the territorial dimension in the analysis of the provincial electoral dynamics in the sub-national elections in Ecuador is still underexplored as most previous works focused on national (legislative) contrary to existing studies in other South American countries (see for instance Tanaka and Guibert 2011; Cerna and Solís 2017).

Conceptually speaking, the nationalization of the provincial elections refers to the fact that the party system and party supply is similar across the country and that both the party and media agendas are dominated by national issues and actors. Furthermore, the nationalization also occurs when voting behaviour is rather uniform across the different provinces and that voters use their ballots to reflect on the political situation at national level. On the other side, the provincialization of the provincial elections occurs when the campaign agenda is dominated by provincial candidates, parties and media. Similarly, in a provincialized electoral process, voters express a behaviour that is guided by purely provincial consideration and vote according to provincial issues and manifesto pledges. The analysis of the 2014 provincial elections demonstrated that - even if national parties remain dominant - a significant process of provincialization was also at play (Dandoy 2014): several national parties concentrated most of their vote shares in a small number of provinces, national parties adopted different strategies according to the provinces (especially regarding alliance formulas) and formed alliances with provincial parties.

This article combines a supply-side analysis (electoral lists) and demand-side (voting behaviour) of the 2019 provincial elections and is structured as follows: a first section presents the typology of parties that 
can be constructed based on the characteristics of parties and candidates competing in these elections, with a particular focus on the territorial dimension and on the presence of provincial parties within the electoral alliances. The second section analyses the performance of the main political parties and alliances for these elections and tests whether the developed party typology constitutes a relevant tool for the explanation of party success and defeat. The phenomena observed to the 2019 elections will be compared with previous provincial elections. The conclusion summarizes the main findings of the article and discusses the issue of the nationalization of the provincial elections in Ecuador.

\section{A typology of parties}

In the 2019 provincial elections, no less than 223 candidates ran for the 23 positions of provincial prefects. On average, it means that there were almost 10 candidates per province. There are significant variations of the number of candidates per province, from three in the province of Carchi up to 20 in the two most populated provinces - Guayas and Pichincha. In comparison, this is almost the double of the amount of candidates in the 2014 provincial elections where 116 candidates were competing (i.e. about five candidates per province).

Even if every single candidate can be related to one - or more existing political party, there is a large diversity of political organizations that presented candidates for the prefectural elections. This article relies on a typology of political parties participating in these elections and relates their main characteristics to their electoral performances. We can distinguish between two main types of candidates: whether they represent a single (or stand-alone) political party or whether they represent an electoral alliance of different political parties. These two main types of candidates can be further subdivided based on the territorial ambition of the parties, i.e. whether they compete at the provincial or at the national level.

According to the Ecuadorian electoral rules (Ley Orgánica Electoral y de Organizaciones Políticas), the definition and several characteristics of 
a political party are legally determined and political parties must register to the National Electoral Council (CNE) in order to be authorized to compete in elections. These administrative barriers limit the number of parties allowed to compete and further distinguish parties based on the level of government they may compete. The CNE distinguishes political parties of national, provincial, cantonal and parochial scope. According to this classification, the Ecuadorian CNE recognized at the end of 2018 no less than 22 parties of national scope, 72 parties of provincial scope, 164 parties of cantonal scope and 16 parties of parochial scope. Given that this article investigates provincial elections, I will only focus on parties that were registered based on a national or on a provincial scope.

\section{Territorial supply}

Even though there are several different ways to distinguish national parties from provincial ones (for an overview, see Dandoy, 2014), this typology is based on the territorial supply of the different political parties. More concretely, the main criterion is the number of provinces where the party presents candidates in elections. As provinces cover the entire Ecuadorian territory, they constitute a valid indicator in order to assess whether a party has a national ambition (in other words, the party competes in all provinces) or a rather a territorial limited ambition (i.e. the party competes in only one province). As a result, I distinguish four types of political parties. First, a 'national party', defined as a party that competes in elections in all the provinces of the country. Second, a 'quasi-national party', a party that competes in elections in a majority of the provinces of the country (i.e. in at least half of the provinces plus one). Third, a 'meta-provincial party', understood as a party that competes in elections in several provinces but not in the majority of them (i.e. in between one and half of the provinces); and third, a 'provincial party', conceptualized as a party that competes in elections in only one province.

Table 1 lists these four different types of parties and displays their relative importance based on two measurements for both the 2014 and 2019 elections. The second column shows the absolute number of candidates 
belonging to each type of party, followed by its relative importance among the overall population of candidates. The fourth column indicates the aggregated number of votes received by all the candidates for each category of parties, followed by the shares of votes for the same category. We notice in this table that the majority of candidates for the provincial elections are attached to one single party. These 160 candidates represent $71,75 \%$ of the total number of candidates. Even if this absolute number of candidates related to standalone parties is much larger than in the previous provincial elections, it is proportionally slightly lower. In 2014, candidates from stand-alone parties represented $72,41 \%$ of the total amount of candidates.

Table 1.

Typology of prefectural candidates (2014 and 2019 provincial elections)

\begin{tabular}{|l|r|r|r|r|r|r|}
\hline & & \multicolumn{1}{|c|}{ Lists } & \multicolumn{1}{c|}{ Lists } & & \multicolumn{1}{c|}{ Votes } & \multicolumn{1}{c|}{ Votes } \\
\cline { 2 - 8 } & N Lists & $\mathbf{2 0 1 9}$ & $\mathbf{2 0 1 4}$ & N Votes & \multicolumn{1}{c|}{$\mathbf{2 0 1 9}$} & \multicolumn{1}{c|}{$\mathbf{2 0 1 4}$} \\
\hline Stand-alone parties & $\mathbf{1 6 0}$ & $\mathbf{7 1 , 7 5} \%$ & $\mathbf{7 2 , 4 1} \%$ & $\mathbf{4 . 4 0 5 . 1 5 8}$ & $\mathbf{5 4 , 4 1} \%$ & $\mathbf{4 8 , 1 2} \%$ \\
\hline National parties & 0 & $0,00 \%$ & $10,34 \%$ & 0 & $0,00 \%$ & $23,13 \%$ \\
\hline Quasi-national parties & 83 & $41,70 \%$ & $35,34 \%$ & 3.126 .378 & $38,62 \%$ & $18,89 \%$ \\
\hline $\begin{array}{l}\text { Meta-provincial } \\
\text { parties }\end{array}$ & 50 & $22,42 \%$ & $19,83 \%$ & 866.1 & $10,70 \%$ & $4,13 \%$ \\
\hline Provincial parties & 17 & $7,63 \%$ & $6,90 \%$ & 412.68 & $5,10 \%$ & $1,97 \%$ \\
\hline & & & & & & \\
\hline \multicolumn{1}{|c|}{ Electoral alliances } & $\mathbf{6 3}$ & $\mathbf{2 8 , 2 5} \%$ & $\mathbf{2 7 , 5 9 \%}$ & $\mathbf{3 . 6 9 0 . 8 4 8}$ & $\mathbf{4 5 , 5 9 \%}$ & $\mathbf{5 1 , 8 8 \%}$ \\
\hline $\begin{array}{l}\text { Without provincial } \\
\text { party }\end{array}$ & 29 & $13,00 \%$ & $10,34 \%$ & 743.812 & $9,19 \%$ & $7,73 \%$ \\
\hline With a provincial party & 34 & $15,25 \%$ & $16,38 \%$ & 2.947 .036 & $36,40 \%$ & $41,46 \%$ \\
\hline $\begin{array}{l}\text { Only with provincial } \\
\text { parties }\end{array}$ & 0 & $0,00 \%$ & $0,86 \%$ & & $0,00 \%$ & $2,68 \%$ \\
\hline & 223 & $100,00 \%$ & $100,00 \%$ & 8.096 .006 & $100,00 \%$ & $100,00 \%$ \\
\hline Total & & & & & & \\
\hline
\end{tabular}


The first criterion in our typology is the total number of provinces where the party competes. In the 2019 provincial elections, no political party presented prefectural candidates in all the 23 provinces of the country where provincial elections were organized. In the 2014 elections, only one party presented candidates in all provinces: the party of the Ecuadorian former president Alianza PAIS. This represents a first finding for the 2019 elections: there are no nationwide political organization or at least no political party was able to present at least one candidate throughout the country, not even the party of the current president Lenin Moreno.

The second category of parties consists in parties that compete in the majority of the provinces of the country: the quasi-national parties. No less than 13 political parties competed in at least 12 provinces. More precisely, four parties presented candidates in almost all provinces: PSC in 20 provinces, CREO in 19 provinces and both Democracia SI and Alianza PAIS in 18 provinces. If these cases quite clearly belong to this type of quasinational parties, there are also a large number of borderline cases. Given that the number of 12 represents the majority of provinces in Ecuador (out of a total of 23 provinces), several parties are around that figure and could be either considered as quasi-national parties or meta-provincial parties. These were the cases of movements like as CD, FCS, ID or Podemos that presented candidates in 12 provinces; UP, EC Unido and F.EC in 11 provinces or LEP, MJS and SUMA in 10 provinces.

The third category of parties is composed of parties that compete in more than one province but in less than he majority of them. This category is labelled meta-provincial parties. No less than ten parties can be attached to this type of party. In addition to the six cases mentioned above, we also find in this category parties such as Avanza (present in nine provinces), Concertacion (eight provinces) and MPD that was present in two provinces only.

The last category of parties identified by their territorial scope deals with provincial parties, i.e. parties that compete in only one province. It concerns 52 different political parties representing the largest group in this typology: 17 as stand-alone parties and 35 in electoral alliances with other parties. Compared to the 2014 provincial elections, it is almost the double 
and, on average, there were more than two provincial parties competing in each province. If provinces like Esmeraldas or Los Rios did not witness the presence of provincial parties in the 2019 elections, some others like Chimborazo or Manabí saw no less than five different provincial parties competing in the prefectural elections.

\section{Electoral alliances}

Besides the total number of provinces where the party competes, a second criterion in our typology concerns the nature of the electoral lists. As in previous provincial and national elections, political parties created electoral alliances in several provinces. In the 2019 provincial elections, 63 candidates were not supported by a single party but by an alliance of different political parties. This represents $28,25 \%$ of the total amount of candidates and a slight increase compared to 2014 (27,59\%).

The CNE allows parties to officially create alliances and gives parties some liberty regarding the nature of these alliances. First, there are no restrictions regarding the number of parties forming alliances, so it is not uncommon to observe alliances made up of five or six parties. In the 2019 provincial elections, the largest alliance was observed in the province of Imbabura where no less than seven parties gathered under the label 'Todos para Imbabura'. Second, these alliances can connect two (or more) national parties, two (or more) provincial parties, or even a mix of national and provincial parties. Our typology mobilises this second element and the classification of alliances has been framed around this structural criteria. We can, therefore, identify three types of alliances depending on the presence of provincial parties.

First, a large group of candidates were supported by an alliance made up exclusively of political parties with national ambition, i.e. quasi-national parties and/or meta-provincial parties. In the Loja province for instance, there were eight candidates competing in the provincial elections, among which two alliances composed of political parties with national ambition: one list gathering PSC, SUMA and Concertacion (under the name 'Por una Loja de 
Oportunidades') and one list composed of MJS and PSE (under the name 'Loja para Todos'). All quasi-national parties joined electoral alliances in at least one province as well as all meta-provincial parties, with the exception of LEP and MPD. Overall, these two parties are the only parties that presented candidates on their own in all the provinces where they competed (10 provinces for LEP and two for MPD).

Second, a majority of electoral alliances were composed of a mix of political parties with national ambition (quasi-national parties or metaprovincial parties) and of provincial parties. Interestingly this mix is almost exclusively composed of one provincial party in alliance with at least one party with national ambition. The only exception to be found is in Chimborazo where one candidate was supported by an alliance of two provincial parties, together with EC Unido and PSC (the Alliance took the name 'Chimborazo Primero'). Going back to our example of Loja, we also observe two alliances that included a provincial party: one list under the name 'Unite al Cambio', gathering EC Unido, Avanza, ID, Pachakutik and the provincial party 'Pueblo, Cambio y Desarrollo', and one list under the name 'Loja Progresa' composed of CREO, AEA, F.EC, UE, Podemos and the provincial party 'Convocatoria por la Unidad Provincial'.

Finally, there were no electoral alliances made up only of provincial parties. But the absence of candidates supported by an exclusively provincial alliance is not a surprise as it confirms the observations from previous elections. In 2014, it occurred only in one instance, i.e. in the province of Azuay for the list 'Alianza Participa con Igualdad'.

\section{Party strategies and performances}

In this section, I investigate the performances of the different types of parties and link election results for the 2019 provincial elections (demand-side) with the typology presented in the first section (supply-side). In other words, it consists in the analysis of the effectiveness of the strategies adopted by the main political parties. Parties had several options at their disposal: present candidates in only one province, in several provinces or in almost all of them, 
as well as participating with a stand-alone lists or in alliances with one or more political parties. This large diversity of strategic options had an impact on the election results obtained by the different parties competing in the provincial elections.

\section{Party strategies}

Table 2 summarizes the party offer (supply-side) for the 2019 elections. It confirms that no party presented candidates in all the provinces of the country. Interesting patterns can be derived from this observation. We have seen above that the large majority of candidates belong to stand-alone parties. This is particularly true for LEP. All 10 candidates attached to this party participated in the prefectural elections under the sole name of the party. The same observation applies to MPD but the party presented candidates in only two provinces.

The ratio between candidates on stand-alone list and candidates in alliances is also positive for a large number of parties. This is particularly the case for FCS and AEA and to a lesser extent for PSP and UE. All these parties presented many more candidates on stand-alone lists than in alliances. On the other side, we observe parties that decided to compete in the provincial elections by joining alliances with other parties rather than with their sole names. For instance, Democracia SI decided to participate in only four provinces as stand-alone party but joined other parties in no less than 14 other provinces throughout the country. It is also the case for parties such as Podemos, PSE, UP or EC_U that favoured the participation in electoral alliances rather than competing alone. Provincial parties also participated proportionally in more electoral alliances than in participating alone in these elections.

It is not only the decision to compete in the elections on its own or to join alliances that allows us to distinguish parties. In fact, the type (and the number) of partners also provides information about the party strategies for the provincial elections. Several parties display a clear preference for alliances with other parties sharing a national ambition. Parties such as FCS, 
Avanza, SUMA or Concertacion clearly gave a priority to alliances with other parties of national ambition. These parties did not enter in an electoral alliance with a provincial party.

On the other hand, we observe parties that tend to favour alliances with provincial parties, sometimes together with other parties of national ambition. ID is a clear example of a party that chose as a strategy an alliance with provincial parties, as six out of its eight candidates proposed in alliances were backed by provincial parties (and in two cases, the provincial party was the only partner). Parties such as PSC, MJS or PAIS also decided to opt for more alliances with provincial parties than for alliances with only parties of national ambition.

Table 2.

Political party landscape (2019 provincial elections)

\begin{tabular}{|l|l|l|l|l|}
\hline \multirow{2}{*}{ Political party } & Stand-alone & Alliance without a & Alliance with a & Total number \\
\cline { 2 - 6 } & party & provincial party & provincial party & of lists \\
\hline CD & 4 & 5 & 3 & 12 \\
\hline UP & 3 & 6 & 2 & 11 \\
\hline PSP & 11 & 2 & 2 & 15 \\
\hline EC Unido & 3 & 6 & 2 & 11 \\
\hline FCS & 11 & 1 & 0 & 12 \\
\hline PSC & 7 & 4 & 9 & 20 \\
\hline AEA & 14 & 1 & 1 & 16 \\
\hline Avanza & 6 & 3 & 0 & 9 \\
\hline LEP & 10 & 0 & 0 & 10 \\
\hline F.EC & 7 & 3 & 1 & 11 \\
\hline MJS & 7 & 1 & 2 & 10 \\
\hline ID & 4 & 2 & 6 & 12 \\
\hline MPD & 2 & 0 & 0 & 2 \\
\hline PSE & 4 & 8 & 3 & 15 \\
\hline
\end{tabular}




\begin{tabular}{|l|l|l|l|l|}
\hline Pachakutik & 8 & 6 & 2 & 16 \\
\hline UE & 11 & 3 & 1 & 15 \\
\hline Democracia SI & 4 & 8 & 6 & 18 \\
\hline CREO & 6 & 5 & 8 & 19 \\
\hline SUMA & 7 & 3 & 0 & 10 \\
\hline Podemos & 3 & 6 & 3 & 12 \\
\hline PAIS & 6 & 4 & 8 & 18 \\
\hline Concertación & 5 & 3 & 0 & 8 \\
\hline $\begin{array}{l}\text { Provincial } \\
\text { parties }\end{array}$ & 17 & - & 35 & 52 \\
\hline
\end{tabular}

Note: The total number of lists in this table overpasses the number of candidates participating in the provincial elections as candidates in alliances are counted for each party that is member of the alliance. Parties have been ranked according to their list number.

\section{Party performances}

We now turn to the election results obtained by these different political parties in the 2019 provincial elections and the comparison with the 2014 elections. Given that many parties decided to form electoral alliances with other parties, the method of calculation has been adapted accordingly. The votes obtained by a party standing alone in one province have been attributed to this party in this province. The votes obtained by an electoral alliance have been equally divided among the parties that compose this alliance. For instance, if an alliance made up of three political parties obtains 6.000 votes in one province, each party will be given 2.000 votes for this province. Finally, the votes gathered by a party have been aggregated for all provinces, independently on the number of provinces where the party was competing.

Table 3 compares the results obtained in 2019 by the 22 parties with national ambition and by all provincial parties with the 2014 provincial elections. The fact that many more parties and candidates participated in these elections had a clear impact on the elections results: votes are more fragmented and the largest party (PSC) obtains 'only' 13,82\% in 2019 while Alianza PAIS - the largest party at that time - managed to obtain $35,45 \%$ in 
2014. ${ }^{3}$ Nevertheless, it does not prevent certain parties to maintain similar results across time as, for instance, CREO that kept its vote shares above 9\% overall at the country level.

Alianza PAIS appears as the main loser of these elections. Even if it participated in less prefectural races than in 2014, the presidential party lost more than $30 \%$ of the total amount of votes and became a mid-size party with less than $5 \%$ of vote shares. Avanza suffered the second largest defeat as the party lost more than $8 \%$ of the votes, partly explained by the fact that it participated in prefectural elections in only 9 provinces. The main winning parties were the newcomers in these elections, such as FCS $(13,60 \%)$ or Democracia SI $(5,24 \%)$. Among the parties that were already present in the 2014 elections, the largest victory has to be attributed to the PSC that increased its vote shares by more than $6 \%$ and became the largest political party in the 2019 provincial elections in Ecuador. This is again partly explained by the fact that the party decided to participate in the elections in no less than 20 provinces (compared to only 7 provinces in 2014). Finally, provincial parties remained as major players in the provincial elections, even if taken together they lost a few votes to parties with national ambition $(-2,09 \%)$.

\section{Table 3.}

Party vote shares (2014-2019 provincial elections)

\begin{tabular}{|l|c|c|c|}
\hline \multirow{2}{*}{ CD } & $\mathbf{2 0 1 9}$ & $\mathbf{2 0 1 4}$ & \multirow{2}{*}{ Difference } \\
\cline { 2 - 3 } & elections & elections & \\
\hline UP & 1,30 & - & $+1,30$ \\
\hline PSP & 2,48 & - & $+2,48$ \\
\hline EC_U & 1,80 & 2,49 & $-0,69$ \\
\hline FCS & 1,13 & - & $+1,13$ \\
\hline PSC & 13,60 & - & $+13,60$ \\
\hline
\end{tabular}

3.- This fragmentation is further exemplified by the fact that no less than 21 parties managed to reach the symbolic threshold of $1 \%$ of the votes. 


\begin{tabular}{|l|r|r|l|}
\hline AEA / PRIAN & 1,60 & 0,52 & $+1,08$ \\
\hline Avanza & 1,71 & 9,79 & $-8,08$ \\
\hline LEP & 0,64 & - & $+0,64$ \\
\hline F.EC / PRE & 2,07 & 0,91 & $+1,16$ \\
\hline MJS & 1,02 & - & $+1,02$ \\
\hline ID & 3,58 & - & $+3,58$ \\
\hline MPD & 1,70 & 2,56 & $-0,86$ \\
\hline PSE / PS-FA & 1,18 & 1,46 & $-0,28$ \\
\hline Pachakutik & 3,50 & 3,37 & $+0,13$ \\
\hline UE & 2,71 & - & $+2,71$ \\
\hline Democracia SI & 5,24 & - & $+5,24$ \\
\hline CREO & 9,04 & 9,37 & $-0,33$ \\
\hline SUMA & 2,58 & 5,16 & $-2,58$ \\
\hline Podemos & 2,29 & - & $+2,29$ \\
\hline PAIS & 4,48 & 35,45 & $-30,97$ \\
\hline Concertacion & 1,73 & - & $+1,73$ \\
\hline Provincial parties & 20,82 & 22,91 & $-2,09$ \\
\hline Total & 100,00 & 100,00 & \\
\hline
\end{tabular}

Note: Parties have been ranked according to their list number. AEA and PRIAN have been considered as similar parties, as well as PSE and PS-FA and F.EC and PRE as they use the same list number.

Another way to look at electoral performances is to cluster parties into categories and to compare the number of candidates for each type of party with their actual electoral performance. Table 1 demonstrated that standalone parties are not proportionally successful compared to the number of candidates presented by these lists: they gather $71,75 \%$ of the candidates but only $54,41 \%$ of the votes in 2019 . If all types of stand-alone parties are concerned by these differences between the number of candidates and the number of votes obtained, it is particularly relevant for meta-provincial parties. With 50 candidates (i.e. more than $22 \%$ of all lists), the metaprovincial parties gather 'only' $11,72 \%$ of the vote shares.

On the contrary, the types of parties that performed best compared to their number of candidates are the electoral alliances: with less than $30 \%$ of 
the candidates, they managed to attract more than $45 \%$ of the votes in 2019 . This is particularly true for the alliances that contain at least one provincial party. These alliances account for $15,25 \%$ of the total number of candidates but they managed to obtain no less than $36,40 \%$ of the vote shares. Another way to look at these figures is to observe the territorial dimension of parties: all the lists that were solely composed of one or several parties with national ambition underperformed compared to their number of candidates. In contrast, it seems that provincial parties (whether as stand-alone parties or in electoral alliances) proportionally gather the best electoral results.

Regression analyses confirm these findings. We pooled the election results for the 2014 and 2019 prefectural elections, for all provinces and all candidates. Table 4 displays the regression models for the 339 candidates in these elections. Candidates have been clustered according to the six types of lists: (1) national parties, (2) quasi-national parties, (3) meta-provincial parties, (4) provincial parties, (5) electoral alliances without a provincial party and (6) electoral alliances with a provincial party ${ }^{4}$. The first model integrates this party typology only while the second model controls for the robustness of our findings by adding two extra variables (election year and the gender of the candidate $)^{5}$. All variables have been operationalized as dummies and we used the meta-provincial parties as a reference category for the types of parties. Several additional models have been run (for instance per election year, excluding national parties or including the number of partners in the alliance) but delivered the same results as in Table 4.

In short, we observe that the type of the electoral list has a significant impact on its performance in the 2014 and 2019 provincial elections. Leaving aside the peculiar lists attached to a national party - it only concerns the 12 candidates belonging to Alianza PAIS in the 2014 elections - we see clearly that provincial parties have a positive impact on election results. Among the

4.- The electoral alliance made up of two provincial parties in the 2014 elections has been included in this group of parties.

5.- Given that the absolute number of candidates was lower in 2014 compared to 2019 , it is normal that the 2014 dummy is positive and significant. On average, parties obtained a larger vote shares in these elections compared to the more recent ones. The gender of the candidate is not significant but negative, indicating that all things being equal - female candidates receive $1,47 \%$ less votes than their male counterparts. 
group of stand-alone parties, provincial parties obtained the largest election results. Taking the meta-provincial parties as the reference category, the provincial parties gather $7,37 \%$ extra votes while the quasi-national also obtain more votes $(+6,49 \%)$ than the meta-provincial ones. But the electoral alliances are even performing better than any group of stand-alone parties: $+13,75 \%$ for the alliances without provincial party and even $+20,27 \%$ for the alliances that integrate a provincial party. Creating an alliance with at least one provincial party can therefore be considered as a credible pathway to electoral success in Ecuador.

\section{Table 4.}

Explaining party performance (2014-2019 provincial elections)

\begin{tabular}{|c|c|c|c|}
\hline & & Model 1 & Model 2 \\
\hline \multirow{7}{*}{ Stand-alone parties } & \multirow{2}{*}{ National } & $40.10877 * * *$ & $36.18643 * * *$ \\
\hline & & -4.190 & -4.253 \\
\hline & \multirow{2}{*}{ Quasi-national } & $6.492223 * * *$ & $6.952061 * * *$ \\
\hline & & -1.952 & -1.924 \\
\hline & Meta-provincial & - & - \\
\hline & \multirow{2}{*}{ Provincial } & $7.370017 *$ & $7.620444 *$ \\
\hline & & -3.165 & -3.093 \\
\hline \multirow{4}{*}{ Electoral alliances } & \multirow{2}{*}{ Without provincial party } & $13.75145 * * *$ & $14.07722 * * *$ \\
\hline & & -2.625 & -2.564 \\
\hline & \multirow{2}{*}{ With provincial party } & $20.26971 * * *$ & $20.21868 * * *$ \\
\hline & & -2.427 & -2.371 \\
\hline \multirow{4}{*}{ Control variables } & \multirow{2}{*}{2014} & \multirow{2}{*}{-} & $6.494613^{* * *}$ \\
\hline & & & -1.565 \\
\hline & \multirow{2}{*}{ Gender } & \multirow{2}{*}{-} & -1.466 \\
\hline & & & -1.994 \\
\hline \multirow{4}{*}{ Model summary } & \multirow{2}{*}{ Constant } & $4.191233 * *$ & 2.108 \\
\hline & & -1.574 & -1.643 \\
\hline & $\mathrm{N}$ & 339 & 339 \\
\hline & Adj R-squared & 0.302 & 0.324 \\
\hline
\end{tabular}

Note: OLS regression. $* * * \rho<0.001 ; * * \rho<0.01 ; * \rho<0.05$. Meta-provincial parties are used as reference category. 


\section{Conclusion}

This article aimed to investigate the 2014 and 2019 provincial elections in Ecuador and to observe the degree to which they can be explained by national factors or whether these elections displayed their own (provincial) dynamics. The research design combined an analysis of the supply-side (electoral lists) and an analysis of the demand-side (voting behaviour) of these provincial elections. The supply-side of the elections relied the development of a typology of parties based on the characteristics of such parties and on their territorial dimension. The demand-side of the elections consists in the analysis of the actual electoral performance of the main political parties and alliances. Ultimately, both viewpoints have been integrated, and this work tests whether the developed party typology constitutes a relevant tool for the explanation of party success and defeat at the provincial level of government.

Provincial elections in Ecuador constitute a perfect case study of mid-term elections, as they are located exactly in the middle of the national electoral agenda. Unsurprisingly, the findings confirm the importance of the national political scene on the voters' electoral behaviour. Parties in the national government are deeply sanctioned by the voters: Alianza PAIS can be considered as the main loser of the 2019 provincial elections, and it saw most of its electorate evaporating. We can find the winners among the new parties and among the main opposition parties (mainly PSC and FCS) at the national level. $77,12 \%$ of all candidates and $58,51 \%$ of all voters can be directly associated with a party with national ambition. Nonetheless, national considerations do not manage to explain the totality of the observed phenomena and some important traces of provincialization can be found in this electoral process.

In Ecuador, national parties, actually are not national. More precisely, there are no nationwide political organizations because no political party was able to present a candidate in all 23 provinces of the country in 2019, not even the party of the current president of the country.

Political parties preferred to focus on some (key) provinces where they could have a chance of winning and preferred not to compete in a series 
of other provinces. In addition, these parties do not always compete on their own - as stand-alone parties - but, very often, they join electoral alliances, together with other parties of national ambition and with provincial parties. Indeed, the presence and strength of the provincial parties constituted one of the key characteristics of the 2019 provincial elections. There were two times more provincial parties compared to the previous elections and their participation in the process can be viewed as a successful.

These elections allowed the development of a renewed typology of the different candidates and lists that competed in the provincial elections. Six different types of electoral lists were identified and the analysis of the election results confirmed the relevance of this typology: the type of party had a direct impact on its electoral performance. Based on these analyses, we were able to identify pathways to electoral victory in the provincial elections in Ecuador in 2014 and 2019. First, the type of parties that performed best compared to their number of candidates are the electoral alliances. Joining other political parties and presenting a common candidate has proven to be a successful strategy, compared to strategies where one party supports its candidate on its own. If the number of partners in the alliance (from two to seven) has no significant impact on the electoral performance, the presence of a provincial party in this alliance is the key to an increased success. Regression analyses demonstrated that alliances with provincial parties provide the best electoral performance. More largely, provincial parties are important actors in the provincial elections in Ecuador. When they participate in the elections on their own, provincial parties are the most successful stand-alone type of parties, and when they join an electoral alliance with other political parties, this provincial 'bonus' is duplicated. 


\section{References}

Cerna Sarah Patricia, Juan Mario Solís (2017) "Los resortes colorados del poder: nacionalización de los partidos y el sistema de partidos paraguayo (1998-2013)", Colombia Internacional, vol. 91, 151-184.

Dandoy Régis (2014) "El desempeño electoral de los partidos politicos provinciales en las elecciones seccionales 2014 en Ecuador", Democracias, vol. 2, pp. 3-19.

Dandoy Régis (2017) "Provincial dynamics in the 2017 national elections in Ecuador", Democracias, vol. 5, pp. 3-24.

Došek T. (2015). "La nacionalización de los partidos y sistemas de partidos en América Latina: Concepto, medición y reciente desarrollo de su estudio en la región”. Política y gobierno, vol. 22(2), pp. 347-390.

Freidenberg Flavia, Simón Pachano, (2016) El sistema político ecuatoriano, Quito: Flacso.

Miller, W.L., and Mackie, M. (1973) “The Electoral Cycle and the Asymmetry of Government and Opposition Popularity: An Alternative Model of the Relationship between Economic Conditions and Political Popularity", Political Studies, vol. 21, pp. 263-279.

Pachano, Simón (2015) 'Desafección política, entusiasmo electoral en Ecuador', in Conde Gutiérrez del Alamo, Rosa, Wences Simon, María Isabel, Cambio político, desafección y elecciones en América Latina, Madrid: Centro de Estudios Políticos y Constitucionales, pp. 171-187.

Polga-Hecimovich, John (2014) ¿"Hacia una superación del "cleavage" regional? La nacionalización de los partidos políticos ecuatorianos desde el retorno a la democracia”, América Latina Hoy, vol. 67, pp. 91-118. 
Sánchez F. (2008) ¿Democracia no lograda o democracia malograda? Un análisis del sistema politico del Ecuador: 1979-2002, Quito: Flacso.

Tanaka Martín, Guibert Yamilé (2011) “Entre la evaporación de los partidos y la debilidad de los movimientos regionales. Una mirada a las elecciones regionales y municipales desde las provincias, 2002-2006-2010", Peru Debate, pp. 18-28.

Tufte, E.R. (1975) "Determinants of the Outcomes of Midterm Congressional Elections", The American Journal of Political Science Review, vol. 69(3), pp. 812-826.

Welp Yanina, Flavia Freidenberg, Pedro Capra (2018) "Nuevos medios, vieja política en las elecciones ecuatorianas de 2014”, Revista Mexicana de Sociología, vol. 80 (4), pp. 827-853. 